\title{
A new record of Spergularia marina (Caryophyllaceae) from southern Poland
}

Artur Pliszko

\begin{abstract}
A new record of Spergularia marina (Caryophyllaceae) from southern Poland. - Acta Mus. Siles. Sci. Natur., 66: 49-51, 2017.

Abstract: Spergularia marina, a rare native halophyte and nationally vulnerable species, is reported from a new locality in southern Poland. It was found on 14 September 2016 in Mogilany, Lesser Poland Voivodeship, growing between paving stones at the Zakopianka road. Map of distribution of $S$. marina in Poland based on the ATPOL cartogram method is provided, and its possible pathways of introduction are discussed.
\end{abstract}

Key words: anthropogenic habitat, distribution, halophyte, red-listed species

\section{Introduction}

Spergularia marina (L.) Griseb, an annual plant of the family Caryophyllaceae, is native to Europe, North Africa, Asia, Australia and North America (Dequan \& Rabeler 2001, Kavak 2014). It has been introduced to South America where is naturalized in Chile and Uruguay (Randall 2012 and literature cited therein). As an obligatory halophyte, it thrives on soils of variable but generally high salinity. It occurs in marine marshes and inland salt pans, being a species characteristic of the salt-marsh community of Spergularia marina-Puccinellia distans (Rodwell 1991, Matuszkiewicz 2008). Interestingly, it has been documented that S. marina can invade roadsides which were salt-treated to melt snow and ice on roads in winter (Scott \& Davison 1982). From a global point of view, S. marina is considered as the least concern species (Kavak 2014).

In Poland, S. marina is a rare native species known from several dozen localities in the north-western, central and southern parts of the country (Zając \& Zając 2001). Its natural stands are restricted to marine and inland salt pans which are distributed along the Baltic Sea shore (Szczecin Lagoon, Bay of Pomerania, Bay of Puck, Bay of Gdańsk), in Kuyavia, Nida Basin and near Wieliczka (Ceynowa-Giełdon 1993, Zając \& Zając 2001). It has been also recorded from anthropogenic habitats such as roadsides, waste dumps and ruderal ground, and its synanthropic stands are known, for example, from Kuyavia, Central Masovian Lowland and Małopolska Upland (Ceynowa-Giełdon 1994, Zając \& Zając 2001, Nobis 2007). Moreover, due to its restricted area of occupancy, $S$. marina is treated as a nationally vulnerable species (Kaźmierczakowa et al. 2016). This paper presents a new record of S. marina from southern Poland.

\section{Material and methods}

Spergularia marina was identified based on morphological characters provided by Rutkowski (2004). Map of distribution was prepared using the ATPOL cartogram method (Zając 1978), where the basic unit is a square of $10 \mathrm{~km}$ side. Occurrence records were obtained from the ATPOL database. Voucher specimens of S. marina are deposited in the Herbarium of the Institute of Botany of the Jagiellonian University in Kraków (KRA). 


\section{Results and discussion}

A new locality of Spergularia marina was discovered on 14 September 2016 in Mogilany, Lesser Poland Voivodeship, southern Poland (GPS coordinates: 49 $55.485^{\prime} \mathrm{N} / 19^{\circ} 52.974^{\prime} \mathrm{E}$, altitude: $260 \mathrm{~m}$ a.s.1.). The locality is situated within the unit DF89 of the ATPOL cartogram grid (Fig. 1). About 50 mature individuals of $S$. marina were found growing between paving stones at the Zakopianka road and associated with a few ruderal plant species, namely Atriplex prostrata Boucher ex DC., Chenopodium glaucum L., Digitaria ischaemum (Schreb.) H. L. Mühl., Eragrostis minor Host, Lepidium ruderale L. and Polygonum aviculare L. Two possible pathways of introduction of $S$. marina can be considered. Presumably, seeds of $S$. marina were introduced to Mogilany by road transport or were transported as a contaminant of salt, which was used to melt the snow and ice on the Zakopianka road in winter. Such pathways of introduction were discussed by Scott \& Davison (1982) who observed the invasion of maritime plants (including $S$. marina) on road verges in the United Kingdom. It should be mentioned that $S$. marina is an alien plant in the local flora of Mogilany, and its nearest native stands are located near Wieliczka, Lesser Poland Voivodeship. The further spread of $S$. marina along salt-treated roads in Poland needs to be studied.

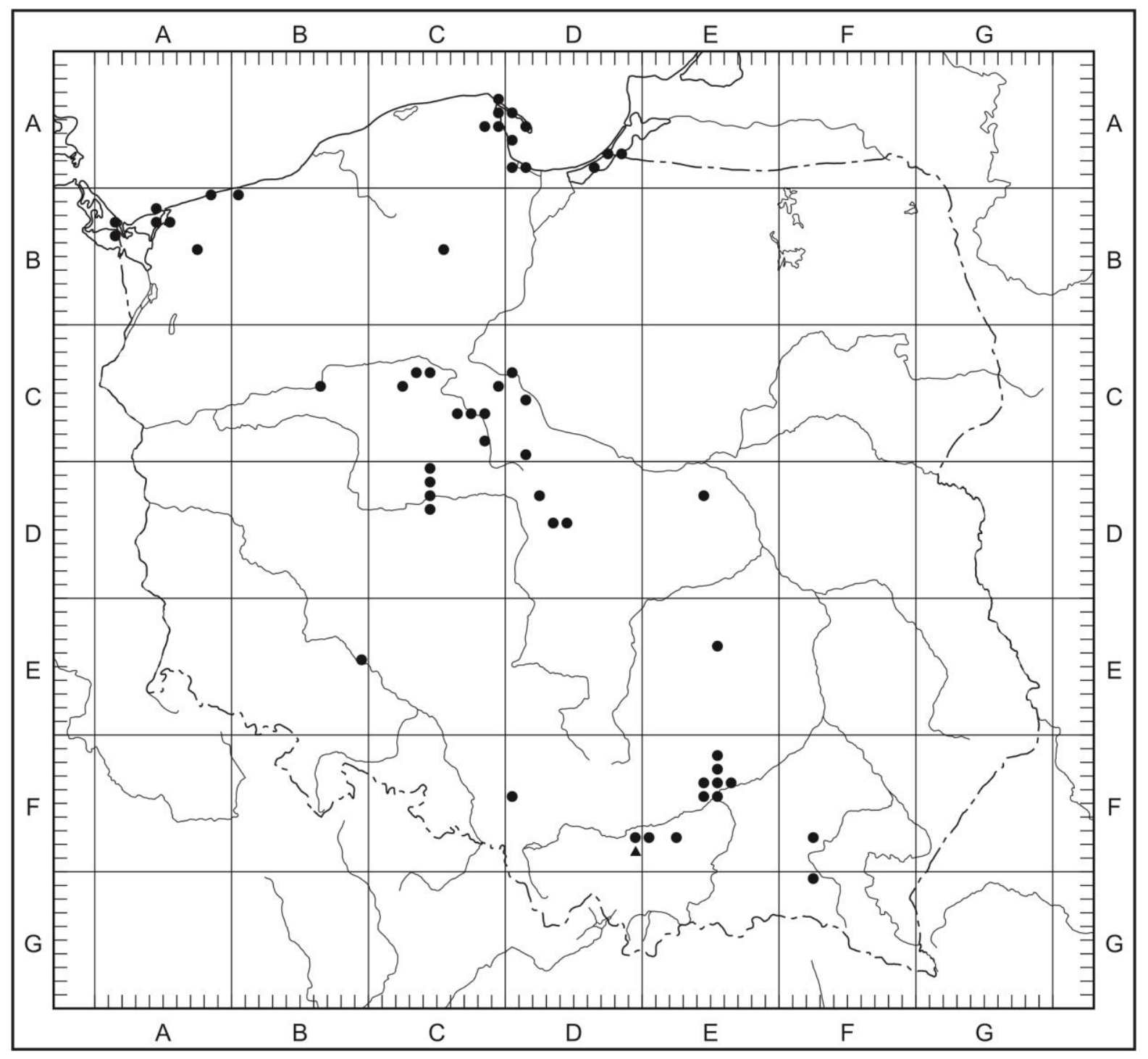

Fig 1: Distribution map of Spergularia marina in Poland ( - known localities; $\boldsymbol{\Delta}-$ new locality). 
Acknowledgements: I would like to thank Professor Maria Zając and Józef Gajda for providing me map of distribution of Spergularia marina in Poland.

\section{References}

Ceynowa-Giełdon M. (1993): The variability of seeds in Spergularia marina (L.) Griseb. (= S. salina J. et C. Presl) growing on seacoast and inland saline soils in Poland. - Acta Soc. Bot. Pol. 62(3-4): 185-191.

- (1994): Anomalies in the structure of Spergularia marina (L.) Griseb. (= S. salina J. et C. Presl) seeds in the area affected by soda industry in Kujawy (central Poland). - Acta Soc. Bot. Pol. 63(3-4): 333-339.

Dequan L. \& Rabeler R.K. (2001): Spergularia (Persoon) J. \& C. Presl. pp. 4-5. In: Wu C.Y., Raven P.H. \& Hong D.Y. (eds): Flora of China, vol. 6, Caryophyllaceae through Lardizabalaceae, Science Press \& Missouri Botanical Garden Press, Beijing \& St. Louis, 512 pp.

Kavak S. (2014): Spergularia marina. The IUCN Red List of Threatened Species 2014: e.T164334A13538043. http://dx.doi.org/10.2305/IUCN.UK.2014-1.RLTS.T164334A13538043.en. (downloaded on 01 Jan 2017).

Kaźmierczakowa R., Bloch-Orłowska J., Celka Z., Cwener A., Dajdok Z., Michalska-Hejduk D., Pawlikowski P., Szczęśniak E. \& Ziarnek K. (2016): Polish red list of pteridophytes and flowering plants. Instytut Ochrony Przyrody Polskiej Akademii Nauk, Kraków, 44 pp.

Matuszkiewicz W. (2008): Przewodnik do oznaczania zbiorowisk roślinnych Polski. Wydawnictwo Naukowe PWN, Warszawa, 537 pp.

Nobis M. (2007): Rośliny naczyniowe zachodniej części Przedgórza Iłżeckiego (Wyżyna Małopolska). - Prace Botaniczne 44: 1-458.

Randall R.P. (2012): A global compendium of weeds. $2^{\text {nd }}$ edition. Department of Agriculture and Food, Western Australia, 1124 pp.

Rodwell J.S. (ed.) (1991): British plant communities, vol. 5. Maritime communities and vegetation of open habitats. Cambridge University Press, Cambridge, 528 pp.

Rutkowski L. (2004): Klucz do oznaczania roślin naczyniowych Polski niżowej. Wydawnictwo Naukowe PWN, Warszawa, 814 pp.

Scott N.E. \& Davison A.W. (1982): De-icing salt and the invasion of road verges by maritime plants. Watsonia 14: 41-52.

Zając A. (1978): Atlas of distribution of vascular plants in Poland (ATPOL). - Taxon 27(5-6): 481-484.

Zając A. \& Zając M. (eds) (2001): Distribution atlas of vascular plants in Poland. Laboratory of Computer Chorology, Institute of Botany, Jagiellonian University, Kraków, 714 pp.

Author's address: Artur Pliszko, Department of Taxonomy, Phytogeography and Paleobotany, Institute of Botany, Jagiellonian University in Kraków, Kopernika 31, 31-501 Kraków, Poland.

E-mail: artur.pliszko@uj.edu.pl 